\title{
The Breast Cancer Patient Experience of Telemedicine During COVID-19
}

\author{
Lina Cadili, MD ${ }^{1}$, Kristin DeGirolamo, MD, FRCS ${ }^{1}$, Crystal Suet-Ying $\mathrm{Ma}^{2,3}$, Leo Chen, $\mathrm{MSc}^{4}$, \\ Elaine McKevitt, MD, FRCS ${ }^{1,2}$, Jin-Si Pao, MD, FRCS ${ }^{1,2}$, Carol Dingee, MD, FRCS $^{1,2}$, \\ Amy Bazzarelli, MD, FRCS ${ }^{1,2}$, and Rebecca Warburton, MD, FRCS ${ }^{1,2}$
}

${ }^{1}$ Division of General Surgery, University of British Columbia, Vancouver, British Columbia, Canada; ${ }^{2}$ Providence Breast Centre, Mount Saint Joseph Hospital, Vancouver, British Columbia, Canada; ${ }^{3}$ Faculty of Science, University of British Columbia, Vancouver, British Columbia, Canada; ${ }^{4}$ Faculty of Medicine, University of British Columbia, Vancouver, British Columbia, Canada

\begin{abstract}
Background. The COVID-19 pandemic has seen major shifts in the delivery of health care across the world, including adoption of telemedicine. We present a survey of patient experience with telemedicine for the treatment of breast cancer.

Methods. A questionnaire designed to assess patient satisfaction with telemedicine was distributed to all patients who underwent surgery at the Providence Breast Centre (PBC) for breast cancer or benign/high-risk lesions with surgery follow-up dates between October 13 and December 31,2020 . Surveys were conducted via phone or at in-person follow-ups.

Results. A total of 123 of $172(72 \%)$ eligible patients completed the survey; $85 \%$ of these patients enjoyed their telemedicine consultation, $93 \%$ found there was enough time for dialogue, $66 \%$ would choose to have a telemedicine consultation again, $79 \%$ would recommend telemedicine at $\mathrm{PBC}$ to a friend or family member, and $92 \%$ found $\mathrm{Zoom}^{\odot}$ easy to use. When asked whether they prefer a telemedicine initial consultation over an in-person, $28 \%$ of patients agreed. When patients are analyzed according to their home address, those more than $10-\mathrm{km}$ away from PBC prefer telemedicine over in-person
\end{abstract}

(C) Society of Surgical Oncology 2021

First Received: 9 August 2021

Accepted: 31 October 2021;

Published Online: 24 November 2021

L. Cadili, MD

e-mail: lina.cadili@alumni.ubc.ca appointments (37\%) more often than those who live less than $10-\mathrm{km}$ away $(23 \%)(p=0.045)$.

Conclusions. Patients report a high level of satisfaction with telemedicine. It may be worthwhile to continue telemedicine beyond the pandemic era, due to its convenience, efficiency, and low-cost while keeping patients, physicians, and office staff safe. It also may be more useful in large geographic areas, such as British Columbia to increase access to care.

One in eight women are expected to develop breast cancer during their lifetime. One in 34 are expected to die of this disease, because it is the number one cancer affecting women. ${ }^{1}$ The Coronavirus Disease 2019 (COVID-19) pandemic has placed many strains on the Canadian healthcare system. Several adjustments were necessary to safely continue providing care for breast patients. One such change was the adoption of telemedicine.

The Providence Breast Centre (PBC) is a high-volume breast center at Mount Saint Joseph Hospital (MSJ) in Vancouver, British Columbia, that was established in 2009, and since this time has been providing care to women with malignant and benign breast disease., ${ }^{2,3}$ The PBC is a multidisciplinary clinic with a centralized referral system that sees patients from across British Columbia. ${ }^{2,3}$ PBC breast surgeons perform approximately 1200 breast surgeries annually, approximately 900 for cancer, and see approximately 9000 patient visits per year. 
Over the past several years, telemedicine has greatly improved in terms of cost, quality, and user-friendliness. ${ }^{4}$ Buvik et al. conducted a randomized, controlled trial to evaluate patient-reported outcomes for virtual consultations and found that there was no difference in patientreported satisfaction and health between video-assisted and standard consultations. The PBC was quick to adopt virtual consultations and follow-up appointments during the COVID-19 pandemic era. Virtual health was conducted either via telephone or video (using $\mathrm{Zoom}^{\odot}$ ); video consultation was encouraged but where access or comfort with technology was limited, telephone appointments were arranged at patient request. "Zoom for Virtual Health Visits" is the platform (audio and video) chosen by our health authority, the Provincial Health Services Authority, for all telemedicine visits as it is "compliant with Canadian privacy regulations, including the Personal Information Protection and Electronic Documents Act (PIPEDA), and locally, the Personal Health Information Protection Act (PHIPA)." 5

All patients at the time of their telemedicine consult were offered in-person, follow-up visits after initial consultation and before surgery. In addition, surgeons organized in-person visits as appropriate for a physical examination for operative planning. The group found that telemedicine was needed to adhere to the public health policies of social distancing, restrictions in waiting rooms, and enhanced cleaning protocols. Adapting to telemedicine reduced some barriers to care and increased the number of opportunities for patient-provider encounters, while reducing health care exposures to patients and staff. Telemedicine clinics therefore may continue beyond the pandemic, but it is crucial to know if our patient population is satisfied with this form of communication. As such, we conducted patient satisfaction surveys to address this.

\section{METHODS}

This quality improvement project was approved by Providence Health Care and the University of British Columbia Research Ethics Board (H20-03444). All patients who had surgery for benign/high risk lesions, DCIS, or breast cancer with postoperative follow-up appointments between October 13 and December 31, 2020, and who had a virtual health consultation as the first meeting with their surgeon were invited to participate. Patients with benign breast disease not requiring surgery, those who were initially seen in-person, those who were unable to complete the survey, and those who declined consenting for the survey were excluded. The questionnaire was administered to eligible participants either in person or via telephone by a dedicated research assistant. The patients who responded to the survey were further subdivided based on their distance from the PBC, either less than or more than $10-\mathrm{km}$ away. Ten kilometers was chosen based on the size of the city of Vancouver, because being more than $10-\mathrm{km}$ away is likely associated with being outside of the city limits.

The questionnaire (Fig. 1) included short questions with responses ranked on a 5-point Likert scale (1 being "strongly disagree" and 5 being "strongly agree") and questions with free text responses. It was developed by the PBC group based on questions thought to be the highest yield, and it was not trialed in a test group prior to deployment. A logistic regression analysis was used to evaluate whether (i) living within $10 \mathrm{~km}$ of a $\mathrm{PBC}$ or (ii) telemedicine modality (Zoom or telephone) was statistically associated with an "agree" or "strongly agree" response to questions scored on the Likert scale. Data analyses were performed using R v4.1.0 and Microsoft Excel v16.45.

\section{Results}

A total of 172 patients who had surgery for benign/highrisk lesions, DCIS, or breast cancer had postoperative follow-up appointments between October 13 and December 31, 2020. Of these 172 eligible patients, 123 completed the survey, yielding a response rate of $72 \%$. All 123 patients included in the survey had a virtual appointment for their first consultation with surgeon. Eighteen patients had multiple visits in person as well as virtual before the study period; they were specifically asked when completing their survey to comment on their initial telemedicine experience.

Most of the patients who completed the survey are female (98\%) with an average age of 54 (range 17-90) years. There was no difference in satisfaction based on age. Most patients had surgery for invasive breast cancer (67/ $123 ; 54.5 \%), 13.8 \%$ for DCIS (17/123), $30.9 \%$ for highrisk or benign lesions (38/123), and $0.8 \%$ for prophylaxis (1/123). Patients in this study had a range of breast surgical procedures. Most patients underwent breast-conserving surgery for cancer or excisional biopsy for high-risk lesions (96/123; 78\%); 46.3\% had preoperative fine wire localization (57/123); 55.3\% (68/123) had a sentinel lymph node biopsy; $2.4 \%$ (3/123) had an axillary lymph node dissection; and 14 patients (11.4\%) underwent mastectomy with immediate reconstructive surgery. Forty-six of the 123 patients live more than $10-\mathrm{km}$ away from the PBC (37.4\%) (Table 1).

Seven survey questions were asked with responses on a 5-point Likert scale, the results of which are displayed in Figure 2. When asked whether they found their telemedicine consultation satisfactory, $94 \%$ of patients agreed 
FIG. 1 Patient questionnaire

PATIENT QUESTIONNAIRE

COVID-19 and Telemedicine at the PBC

1. I found my telemedicine consultation satisfactory.

\begin{tabular}{|c|c|c|c|c|}
\hline $\begin{array}{c}\text { Strongly } \\
\text { Disagree }\end{array}$ & Disagree & Neutral & Agree & $\begin{array}{c}\text { Strongly } \\
\text { Agree }\end{array}$ \\
\hline 1 & 2 & 3 & 4 & 5 \\
\hline
\end{tabular}

2. There was enough time for dialogue and for me to ask questions.

\begin{tabular}{|c|c|c|c|c|}
\hline $\begin{array}{c}\text { Strongly } \\
\text { Disagree }\end{array}$ & Disagree & Neutral & Agree & $\begin{array}{c}\text { Strongly } \\
\text { Agree }\end{array}$ \\
\hline 1 & 2 & 3 & 4 & 5 \\
\hline
\end{tabular}

3. I enjoyed my telemedicine consultation.

\begin{tabular}{|c|c|c|c|c|}
\hline $\begin{array}{c}\text { Strongly } \\
\text { Disagree }\end{array}$ & Disagree & Neutral & Agree & $\begin{array}{c}\text { trongly } \\
\text { Agree }\end{array}$ \\
\hline 1 & 2 & 3 & 4 & 5 \\
\hline
\end{tabular}

4. I prefer a telemedicine initial consultation over an in-person consultation.

\begin{tabular}{|c|c|c|c|c|}
\hline $\begin{array}{c}\text { Strongly } \\
\text { Disagree }\end{array}$ & Disagree & Neutral & Agree & $\begin{array}{c}\text { Strongly } \\
\text { Agree }\end{array}$ \\
\hline 1 & 2 & 3 & 4 & 5 \\
\hline
\end{tabular}

5. I would choose a telemedicine appointment again.

\begin{tabular}{|c|c|c|c|c|}
\hline $\begin{array}{c}\text { Strongly } \\
\text { Disagree }\end{array}$ & Disagree & Neutral & Agree & $\begin{array}{c}\text { Strongly } \\
\text { Agree }\end{array}$ \\
\hline 1 & 2 & 3 & 4 & 5 \\
\hline
\end{tabular}

6. I found Zoom easy to use (omit this question if patient had a telephone consultation).

\begin{tabular}{|c|c|c|c|c|}
\hline $\begin{array}{c}\text { Strongly } \\
\text { Disagree }\end{array}$ & Disagree & Neutral & Agree & $\begin{array}{c}\text { Strongly } \\
\text { Agree }\end{array}$ \\
\hline 1 & 2 & 3 & 4 & 5 \\
\hline
\end{tabular}

7. I would recommend telemedicine at $\mathrm{PBC}$ to a family member or friend.

\begin{tabular}{|c|c|c|c|c|}
\hline $\begin{array}{c}\text { Strongly } \\
\text { Disagree }\end{array}$ & Disagree & Neutral & Agree & $\begin{array}{c}\text { Strongly } \\
\text { Agree }\end{array}$ \\
\hline 1 & 2 & 3 & 4 & 5 \\
\hline
\end{tabular}

8. What did you like about the telemedicine process?

9. What did you NOT like about the telemedicine process?

10. How could we improve this process for you? 
TABLE 1 Demographic information of people who completed the survey

\begin{tabular}{lll}
\hline Variable & Level & Summary \\
\hline Sex $(\mathrm{n}, \%)$ & Female & $121(98.4 \%)$ \\
Age & Male & $2(1.6 \%)$ \\
Driving distance $10 \mathrm{~km}$ away from PBC $(n, \%)$ & Mean \pm SD & $54.3 \pm 14.7$ \\
& Median $(\mathrm{Q} 1$ to Q3) & $55.0(45$ to 65) \\
Indication for surgery $(n, \%)$ & No & $77(62.6 \%)$ \\
& Yes & $46(37.4 \%)$ \\
& Benign/high-risk Lesions & $38(3.9 \%)$ \\
Type of surgery $(n, \%)$ & DCIS & $17(13.8 \%)$ \\
& Malignant & $67(54.5 \%)$ \\
Reconstruction $(n, \%)$ & Prophylaxis & $1(0.8 \%)$ \\
Fine wire localization $(n, \%)$ & Breast conserving surgery & $96(78.0 \%)$ \\
Axillary procedure $(n, \%)$ & Mastectomy & $25(20.3 \%)$ \\
& Other & $2(1.6 \%)$ \\
& No & $109(88.6 \%)$ \\
& Yes & $14(11.4 \%)$ \\
& No & $66(53 . \& \%)$ \\
& Yes & $57(46.3 \%)$ \\
& SLNB & $68(55.3 \%)$ \\
& ALND & $3(2.4 \%)$ \\
& None & $52(42.3 \%)$ \\
\hline
\end{tabular}

or strongly agreed (115/123). Most patients also found that there was enough time for dialogue and to ask questions $(115 / 123,94 \%) ; 85 \%$ of patients agreed or strongly agreed that they enjoyed their telemedicine consultation (104/ 123). However, only 34 of 123 patients (28\%) agreed or strongly agreed that they prefer a telemedicine initial consultation over an in-person consultation. When asked if they would choose a telemedicine appointment again, 66\% of patients agreed or strongly agreed (81/123). Eighty-three of the 123 patients $(67.4 \%)$ who responded to the survey used Zoom; the rest had their initial consultation via telephone. Seventy-seven of the 83 patients who used Zoom agreed or strongly agreed that they found it easy to use $(92.8 \%)$. When asked if they would recommend telemedicine at $\mathrm{PBC}$ to a family member or friend, 97 of 123 patients agreed or strongly agreed (79\%).

When comparing patient satisfaction for those who had their consultation via Zoom versus telephone, patients who had their consultation via Zoom found it to be satisfactory and found that there was enough time for dialogue and questions $90 \%$ of the time $(75 / 83)$ versus $100 \%$ of patients who had a telephone consultation $(39 / 39 ; p=0.992)$. Also, $83 \%(69 / 83)$ of the Zoom patients and $90 \%$ of the telephone patients $(36 / 40)$ enjoyed their consultation $(p=$ 0.318 ). Only $21.7 \%$ of Zoom patients (18/83) preferred their consultation over an in-person consultation, and $42.5 \%$ of telephone patients (17/40) preferred their consultation over in-person $(p=0.018)$. Only $62.7 \%$ of Zoom patients $(52 / 83)$ and $72.5 \%$ of telephone patients $(29 / 40)$ would choose a telemedicine appointment again $(p=$ 0.282). Most patients $(76 / 83,91.6 \%)$ found Zoom easy to use; two patients who had both a Zoom and telephone consultation responded to question 6 . Also, $78 \%$ of the Zoom patients $(65 / 83)$ and $80 \%$ of the telephone patients (32/40) would recommend telemedicine at PBC to a family member or friend ( $p=0.720$; Table 2$)$.

The 123 patients who responded to the survey were further divided into two groups based on their distance from the PBC: more than or less than 10-km away. Twelve of the patients live more than $50-\mathrm{km}$ away from the PBC. Patients living more than $10-\mathrm{km}$ away from the $\mathrm{PBC}$ agreed that they prefer a telemedicine initial consultation over an in-person consultation $(p=0.045)$ compared with people who live less than $10-\mathrm{km}$ away from the PBC (Table 3). There was no statistically significant difference between their responses to the rest of the survey. All patients had a physical examination before surgery; it was either booked as an in-person appointment before the day of the surgery or the patient was examined on the day of surgery. Fifty-eight of the 172 patients had an in-person appointment scheduled for a physical examination before their surgery date. Survey responses also were divided based on whether the patient had a preoperative physical examination appointment. Those who had a physical examination reported greater satisfaction with telemedicine for all the survey questions compared with their counterparts who had a physical examination on the day of surgery. 
FIG. 2 Responses to patient survey questions. $1=$ strongly disagree, 2 = disagree, $3=$ neutral, $4=$ agree, $5=$ strongly agree
Q1: “I enjoyed my telemedicine consultation."

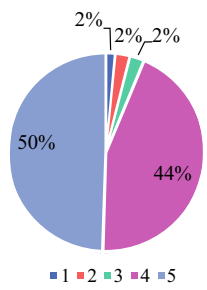

Q2: "There was enough time for dialogue and for me to ask question."

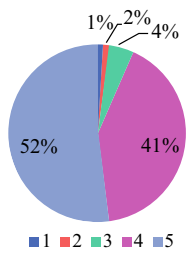

Q4: "I prefer a telemedicine initial consultation over an in-person consultation."

Q3: "I enjoyed my telemedicine consultation."
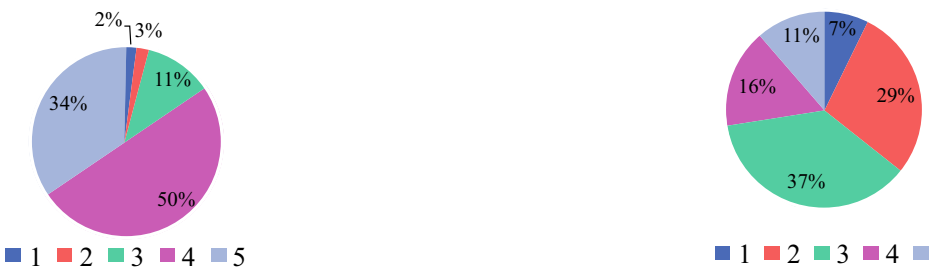

$\square 1 \square 2 \square 3 \square 4 \square 5$

Q6: "I found Zoom easy to use."

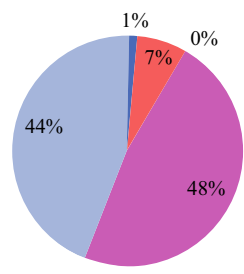

$\square 1 \backsim 2 \backsim 3 \backsim 4 \backsim 5$

Q7: "I would recommend a telemedicine at PBC to a family member or friend."

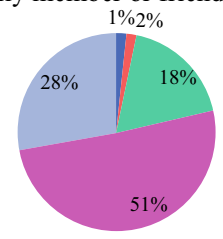

$\square 1 \square 2 \square 3 \square 4 \square 5$

\section{Discussion}

The COVID-19 pandemic has altered the delivery of healthcare services quite dramatically. In order to reduce person-to-person contact and transmission of the virus and comply with public health rules, telemedicine has been adopted worldwide. ${ }^{6}$ As discussed by Monaghesh et al., telemedicine can mobilize all aspects of healthcare potentials to protect patients, clinicians, and the community from exposure to infection and diminish the burden on the healthcare providers and the health system. The Providence Breast Centre at Mount Saint Joseph's Hospital in Vancouver, British Columbia, sees patients from across the province and was quick to adapt to telemedicine. British Columbia is a large province in Western Canada with a population of 5071,336 (as of 2019), ${ }^{7}$ distributed across a wide geographical area covering $944,735 \mathrm{~km} .^{2}$ Forty-six of the 123 patients $(37 \%)$ who completed our survey regarding telemedicine during the COVID-19 pandemic live more than 10-km away from the PBC.

Overall, it is clear from our survey responses that our patients had a positive experience with telemedicine. Most patients enjoyed it, found that there was enough time for dialogue and questions, would choose telemedicine again, and would recommend telemedicine to a friend or family member. Patients specifically commented on how the experience was "flexible, safe, and convenient." They enjoyed "seeing their own images and results on the shared screen" and particularly felt comfortable "having their family members able to participate in the appointment," as 
TABLE 2 Patient survey responses based on telephone versus zoom consultation

\begin{tabular}{|c|c|c|c|c|}
\hline Question & Response & $\begin{array}{l}\text { Zoom }(n= \\
83)\end{array}$ & $\begin{array}{l}\text { Telephone }(n= \\
40)\end{array}$ & $\begin{array}{l}p \text { value (strongly agree or agree } \\
\text { vs. not) }\end{array}$ \\
\hline \multirow[t]{5}{*}{ Q1 "I found my telemedicine consultation satisfactory." } & $\begin{array}{l}\text { Strongly } \\
\text { agree }\end{array}$ & $36(43.4 \%)$ & $25(62.5 \%)$ & \multirow[t]{5}{*}{0.992} \\
\hline & Agree & $39(47.0 \%)$ & $15(37.5 \%)$ & \\
\hline & Neutral & $3(3.6 \%)$ & $0(0.0 \%)$ & \\
\hline & Disagree & $3(3.6 \%)$ & $0(0.0 \%)$ & \\
\hline & $\begin{array}{l}\text { Strongly } \\
\text { disagree }\end{array}$ & $2(2.4 \%)$ & $0(0.0 \%)$ & \\
\hline \multirow[t]{5}{*}{$\begin{array}{l}\text { Q2 "There was enough time for dialogue and for me to ask } \\
\text { questions." }\end{array}$} & $\begin{array}{l}\text { Strongly } \\
\text { agree }\end{array}$ & $38(45.8 \%)$ & $26(65.0 \%)$ & \multirow[t]{5}{*}{0.992} \\
\hline & Agree & $37(44.6 \%)$ & $14(35.0 \%)$ & \\
\hline & Neutral & $5(6.0 \%)$ & $0(0.0 \%)$ & \\
\hline & Disagree & $2(2.4 \%)$ & $0(0.0 \%)$ & \\
\hline & $\begin{array}{l}\text { Strongly } \\
\text { disagree }\end{array}$ & $1(1.2 \%)$ & $0(0.0 \%)$ & \\
\hline \multirow[t]{5}{*}{ Q3 "I enjoyed my telemedicine consultation." } & $\begin{array}{r}\text { Strongly } \\
\text { Agree }\end{array}$ & $22(26.5 \%)$ & $20(50.0 \%)$ & \multirow[t]{5}{*}{0.318} \\
\hline & Agree & $47(56.6 \%)$ & $16(40.0 \%)$ & \\
\hline & Neutral & $9(10.8 \%)$ & $4(10.0 \%)$ & \\
\hline & Disagree & $3(3.6 \%)$ & $0(0.0 \%)$ & \\
\hline & $\begin{array}{l}\text { Strongly } \\
\text { disagree }\end{array}$ & $2(2.4 \%)$ & $0(0.0 \%)$ & \\
\hline \multirow[t]{5}{*}{$\begin{array}{l}\text { Q4 "I prefer a telemedicine initial consultation over an in- } \\
\text { person consultation." }\end{array}$} & $\begin{array}{l}\text { Strongly } \\
\text { agree }\end{array}$ & $6(7.2 \%)$ & $8(20.0 \%)$ & \multirow[t]{5}{*}{0.018} \\
\hline & Agree & $12(14.5 \%)$ & $9(22.5 \%)$ & \\
\hline & Neutral & $33(39.8 \%)$ & $11(27.5 \%)$ & \\
\hline & Disagree & $24(28.9 \%)$ & $11(27.5 \%)$ & \\
\hline & $\begin{array}{l}\text { Strongly } \\
\text { disagree }\end{array}$ & $8(9.6 \%)$ & $1(2.5 \%)$ & \\
\hline \multirow[t]{5}{*}{ Q5 "I would choose a telemedicine appointment again." } & $\begin{array}{l}\text { Strongly } \\
\text { agree }\end{array}$ & $12(14.5 \%)$ & $10(25.0 \%)$ & \multirow[t]{5}{*}{0.282} \\
\hline & Agree & $40(48.2 \%)$ & $19(47.5 \%)$ & \\
\hline & Neutral & $21(25.3 \%)$ & $6(15.0 \%)$ & \\
\hline & Disagree & $6(7.2 \%)$ & $5(12.5 \%)$ & \\
\hline & $\begin{array}{l}\text { Strongly } \\
\text { disagree }\end{array}$ & $4(4.8 \%)$ & $0(0.0 \%)$ & \\
\hline \multirow[t]{5}{*}{ Q6 "I found Zoom $@$ easy to use." } & $\begin{array}{l}\text { Strongly } \\
\text { agree }\end{array}$ & $37(45.1 \%)$ & $0(0.0 \%)$ & \multirow[t]{5}{*}{0.086} \\
\hline & Agree & $39(47.6 \%)$ & $1(50.0 \%)$ & \\
\hline & Neutral & $0(0.0 \%)$ & $0(0.0 \%)$ & \\
\hline & Disagree & $5(6.1 \%)$ & $1(50.0 \%)$ & \\
\hline & $\begin{array}{l}\text { Strongly } \\
\text { disagree }\end{array}$ & $1(1.2 \%)$ & $0(0.0 \%)$ & \\
\hline \multirow[t]{5}{*}{$\begin{array}{l}\text { Q7 "I would recommend telemedicine at PBC to a family } \\
\text { member or friend." }\end{array}$} & $\begin{array}{l}\text { Strongly } \\
\text { agree }\end{array}$ & $21(25.6 \%)$ & $13(33.3 \%)$ & \multirow[t]{5}{*}{0.720} \\
\hline & Agree & $44(53.7 \%)$ & $19(48.7 \%)$ & \\
\hline & Neutral & $14(17.1 \%)$ & $5(12.8 \%)$ & \\
\hline & Disagree & $1(1.2 \%)$ & $2(5.1 \%)$ & \\
\hline & $\begin{array}{l}\text { Strongly } \\
\text { disagree }\end{array}$ & $2(2.4 \%)$ & $0(0.0 \%)$ & \\
\hline
\end{tabular}


TABLE 3 Patient survey responses based on patient distance from the PBC

\begin{tabular}{|c|c|c|c|c|}
\hline Question & Response & $\begin{array}{l}\text { Less than } 10 \mathrm{~km} \\
\text { from PBC }\end{array}$ & $\begin{array}{l}\text { More than } 10 \mathrm{~km} \\
\text { from PBC }\end{array}$ & $\begin{array}{l}p \text { value (strongly agree or } \\
\text { agree vs. not) }\end{array}$ \\
\hline \multirow[t]{5}{*}{$\begin{array}{l}\text { Q1 "I found my telemedicine consultation } \\
\text { satisfactory." }\end{array}$} & $\begin{array}{l}\text { Strongly } \\
\text { agree }\end{array}$ & $37(48.1 \%)$ & $24(52.2 \%)$ & \multirow[t]{5}{*}{0.995} \\
\hline & Agree & $35(45.5 \%)$ & $19(41.3 \%)$ & \\
\hline & Neutral & $0(0.0 \%)$ & $3(6.5 \%)$ & \\
\hline & Disagree & $3(3.9 \%)$ & $0(0.0 \%)$ & \\
\hline & $\begin{array}{l}\text { Strongly } \\
\text { disagree }\end{array}$ & $2(2.6 \%)$ & $0(0.0 \%)$ & \\
\hline \multirow[t]{5}{*}{$\begin{array}{l}\text { Q2 "There was enough time for dialogue and for me to } \\
\text { ask questions." }\end{array}$} & $\begin{array}{l}\text { Strongly } \\
\text { agree }\end{array}$ & $40(51.9 \%)$ & $24(52.2 \%)$ & \multirow[t]{5}{*}{0.451} \\
\hline & Agree & $33(42.9 \%)$ & $18(39.1 \%)$ & \\
\hline & Neutral & $4(5.2 \%)$ & $1(2.2 \%)$ & \\
\hline & Disagree & $0(0.0 \%)$ & $2(4.3 \%)$ & \\
\hline & $\begin{array}{l}\text { Strongly } \\
\text { disagree }\end{array}$ & $0(0.0 \%)$ & $1(2.2 \%)$ & \\
\hline \multirow[t]{5}{*}{ Q3 "I enjoyed my telemedicine consultation." } & $\begin{array}{l}\text { Strongly } \\
\text { agree }\end{array}$ & $26(34.7 \%)$ & $15(33.3 \%)$ & \multirow[t]{5}{*}{0.700} \\
\hline & Agree & $38(50.7 \%)$ & $24(53.3 \%)$ & \\
\hline & Neutral & $8(10.7 \%)$ & $5(11.1 \%)$ & \\
\hline & Disagree & $2(2.7 \%)$ & $1(2.2 \%)$ & \\
\hline & $\begin{array}{l}\text { Strongly } \\
\text { disagree }\end{array}$ & $1(1.3 \%)$ & $0(0.0 \%)$ & \\
\hline \multirow[t]{5}{*}{$\begin{array}{l}\text { Q4 "I prefer a telemedicine initial consultation over an } \\
\text { in-person consultation." }\end{array}$} & $\begin{array}{l}\text { Strongly } \\
\text { agree }\end{array}$ & $7(9.7 \%)$ & $7(15.6 \%)$ & \multirow[t]{5}{*}{0.045} \\
\hline & Agree & $10(13.9 \%)$ & $10(22.2 \%)$ & \\
\hline & Neutral & $26(36.1 \%)$ & $14(31.1 \%)$ & \\
\hline & Disagree & $21(29.2 \%)$ & $13(28.9 \%)$ & \\
\hline & $\begin{array}{l}\text { Strongly } \\
\text { disagree }\end{array}$ & $8(11.1 \%)$ & $1(2.2 \%)$ & \\
\hline \multirow[t]{5}{*}{$\begin{array}{l}\text { Q5 "I would choose a telemedicine appointment } \\
\text { again." }\end{array}$} & $\begin{array}{l}\text { Strongly } \\
\text { agree }\end{array}$ & $10(14.1 \%)$ & $12(26.7 \%)$ & \multirow[t]{5}{*}{0.067} \\
\hline & Agree & $36(50.7 \%)$ & $23(51.1 \%)$ & \\
\hline & Neutral & $15(21.1 \%)$ & $7(15.6 \%)$ & \\
\hline & Disagree & $7(9.9 \%)$ & $2(4.4 \%)$ & \\
\hline & $\begin{array}{l}\text { Strongly } \\
\text { disagree }\end{array}$ & $3(4.2 \%)$ & $1(2.2 \%)$ & \\
\hline \multirow[t]{5}{*}{ Q6 "I found Zoom@ easy to use." } & $\begin{array}{l}\text { Strongly } \\
\text { agree }\end{array}$ & $25(50.0 \%)$ & $12(36.4 \%)$ & \multirow[t]{5}{*}{0.507} \\
\hline & Agree & $20(40.0 \%)$ & $20(60.6 \%)$ & \\
\hline & Neutral & $0(0.0 \%)$ & $0(0.0 \%)$ & \\
\hline & Disagree & $5(10.0 \%)$ & $1(3.0 \%)$ & \\
\hline & $\begin{array}{l}\text { Strongly } \\
\text { disagree }\end{array}$ & $0(0.0 \%)$ & $0(0.0 \%)$ & \\
\hline \multirow[t]{5}{*}{$\begin{array}{l}\text { Q7 "I would recommend telemedicine at PBC to a } \\
\text { family member or friend." }\end{array}$} & $\begin{array}{l}\text { Strongly } \\
\text { agree }\end{array}$ & $15(20.3 \%)$ & $19(42.2 \%)$ & \multirow[t]{5}{*}{0.336} \\
\hline & Agree & $44(59.5 \%)$ & $19(42.2 \%)$ & \\
\hline & Neutral & $11(14.9 \%)$ & $7(15.6 \%)$ & \\
\hline & Disagree & $2(2.7 \%)$ & $0(0.0 \%)$ & \\
\hline & $\begin{array}{l}\text { Strongly } \\
\text { disagree }\end{array}$ & $2(2.7 \%)$ & $0(0.0 \%)$ & \\
\hline
\end{tabular}


some patients were able to share the Zoom link with family and friends from geographically diverse regions. Telemedicine potentially has implications for delivery of health care beyond the pandemic era, particularly for oncological patients who may be immunocompromised and at greater risk when coming to the hospital regularly for appointments. Telemedicine is particularly advantageous for those patients in rural communities, because it would cut down the burdens of travel quite substantially and possibly introduce greater efficiency into oncology care beyond the pandemic. $^{8}$ From the short-answer survey questions, patients specifically commented on how their virtual appointment saved them from "dealing with traffic and parking and the burdens of traveling." Given the unpredictable nature of a pandemic, Booth et al. anticipate that telemedicine will be critical to balance patient outcomes with system capacity when anticipated quarantines, isolations, and hospitalizations affect the capacity to deliver cancer care. ${ }^{9}$

Despite our patients enjoying telemedicine, it is important to discuss that only $28 \%$ of patients (34/123) agreed or strongly agreed to preferring telemedicine initial consultation over an in-person consultation. When further analyzed based on the type of consultation, less patients preferred their consultation compared with in-person if they had their consultation via Zoom $(21.7 \%)$ versus telephone $(42.5 \%)$. Some patients felt that "it would be nice to have a face-to-face interaction for the first meeting" and at times the appointment "felt impersonal, as if the surgeon was on a work call." Others also commented on their preference of "being examined by the surgeon" and also "felt anxious when the connection was not working." This lack of familiarity with online services and obvious limitation of the absence of a physical examination at the first visit can be quite stressful for patients. Without a physical examination before surgery, the initial visit with the surgeon can feel impersonal to the patient. Particularly for an oncological patient, they may feel more at ease if a surgeon conducts a thorough physical examination to ensure nothing else is missed. The clinic organized in-person visits upon request of the surgeon or patient after consultation and once accepted into the clinic to ease anxiety. The patients who did have a physical examination before surgery reported greater satisfaction with telemedicine than those who were examined on the day of surgery.

Most studies on telemedicine have focused on follow-up visits or those with established provider-patient relationships prior to the pandemic. Our study is unique, because telemedicine was the first encounter between the patient and surgeon, often disclosing a cancer diagnosis or within days of a new cancer diagnosis. Also, a strength of our study is our methodology; we were able to achieve a high survey response rate of $72 \%$ by recruiting research assistants to deliver the survey linked to the patient's postoperative appointments. That being said, one limitation of the study is that we do not have a large cohort, because we selected a short window of time to collect data to ensure patient satisfaction with the adapted mode of delivery of care during the ongoing pandemic. It would be critical to conduct this survey in a few years after the pandemic to determine whether patients continue to enjoy their telemedicine experience beyond the pandemic phase. Another area of future study would be to review whether the lack of a preoperative physical examination increased the risk of having an unoptimized surgery (e.g., ordering a fine wire for a palpable lesion as reported by the patient but surgeon was unsure if it would be palpable) and the effect on surgical margins. Lastly, it would be interesting to distribute a questionnaire to the surgeons to investigate satisfaction with telemedicine from their perspective as a future study.

\section{Conclusions}

The COVID-19 pandemic placed several strains on the healthcare system, requiring clinicians and patients to adapt in several ways, one of which is the implementation of telemedicine. The PBC was quick to adopt virtual consultations and follow-up appointments, and a majority of patients enjoyed their telemedicine experience, although they would prefer their initial consultation to be in-person. Patients were generally more satisfied with telephone appointments compared with Zoom. Patients who lived more than $10-\mathrm{km}$ away from the breast center reported higher satisfaction with telemedicine. Going forward, telemedicine should be tailored to patient comfort with technology, with more institutional support for patient access. Telemedicine has proven to be an efficient, effective, and safe method of communication for oncology patients, particularly in a geographically vast area, such as British Columbia, which likely will continue beyond the pandemic era.

ACKNOWLEDGMENTS The authors acknowledge Mabel Zhang, our research assistant, who helped with data collection.

FUNDING No funding was provided for this study.

DISCLOSURES The authors declare no conflicts of interest.

\section{REFERENCES}

1. BC Cancer Provincial Health Services Authority. Statistics by cancer type - breast. Cancer Surveillance and Outcomes. Population Oncol. 2019. http://www.bccancer.bc.ca/statistics-and-re ports-site/Documents/Cancer_Type_Brain_2017_20200327.pdf. Accessed 10 Sept 2020. 
2. Providence Breast Centre at Mount Saint Joseph Hospital. http:// www.msjbreastclinic.com/. Accessed 10 Sept 2020.

3. Cha J, McKevitt E, Pao J-S, Dingee C, Bazzarelli A, Warburton R. Access to surgery following centralization of breast cancer surgical consultations. Am J Surg. 2020. https://doi.org/10.1016/j.amjsurg. 2020.01.050.

4. Buvik A, Bugge E, Knutsen G, Småbrekke A, Wilsgaard T. Patient reported outcomes with remote orthopaedic consultations by telemedicine: a randomised controlled trial. J Telemed Telecare. 2018. https://doi.org/10.1177/1357633x18783921.

5. Zoom for Virtual Health Visits Manual. Provincial Health Services Authority. Version 1.0 - July 19, 2021. http://www.phsa.ca/healthprofessionals-site/Documents/Office $\% 20$ of $\% 20$ Virtual $\% 20 \mathrm{Health} /$ PHSA\%20Zoom\%20Manual\%20v1.pdf> Accessed 8 Sept 2021.

6. Monaghesh E, Hajizadeh A. The role of telehealth during COVID19 outbreak: a systematic review based on current evidence. $B M C$ Public Health. 2020. https://doi.org/10.1186/s12889-020-09301-4.
7. BC Population Estimates. https://www2.gov.bc.ca/gov/content/da ta/statistics/people-population-community/population/population-e stimates. Accessed 15 Feb 2021.

8. Loree JM, Dau H, Rebić N, et al. Virtual oncology appointments during the initial wave of the COVID-19 pandemic: an international survey of patient perspectives. Curr Oncol. 2021. https://doi. org/10.3390/curroncol28010065.

9. Hanna TP, Evans GA, Booth CM. Cancer, COVID-19 and the precautionary principle: prioritizing treatment during a global pandemic. Nat Rev Clin Oncol. 2020. https://doi.org/10.1038/s41 571-020-0362-6.

Publisher's Note Springer Nature remains neutral with regard to jurisdictional claims in published maps and institutional affiliations. 